\title{
Neotectonic Evidences in Guwair-Humaira Area SE Mosul-Iraq
}

\author{
Salim Q. Al-Naqib \\ Dams and Water \\ Resources Center \\ University of Mosul
}

\author{
Hekmet S. Al-Daghstani \\ Remote Sensing Center \\ University of Mosul
}

\author{
Ahmed M. Al-Taie \\ Department of Geology \\ College of Science \\ University of Tikrit
}

(Received 20/5/2018 ，Accepted 10/7/2018)

\begin{abstract}
Neotectonic evidences were detected along Kirkuk-Najd- fault system that passes towards N45W along Guwair anticline, Humaira, Hawi Aslan, Zanquba and Mosul city through the Tigris River belt passing towards Iraqi- Syrian-Turkish borders. Ninivite persists through these localities. Two sets of slickensides forming two shear movements, restricting two acute angles $60^{\circ}$ and $32^{\circ}$ respectively, have their clear imprints on the newly formed Ninivite.

Geochemical work concerning oxides distribution and element movements enrolled mainly by $\mathrm{pH}$ declinations through sample distribution assured the structural imprint of slickensides on a Ninivite rock on sample distribution covering unaltered and altered phases. Two main alteration events were picked up through samples 14 and 16 respectively. These events marked $\mathrm{H}_{2} \mathrm{~S}$ and $\mathrm{CH}_{4}$ gas seepages produced as a result of any newly detected seismic activities. The analysis of stress refers to the $\mathrm{N} 45 \mathrm{~W}$ i.e. rejuvenation of Kirkuk-Najd fault system. During alteration, $\mathrm{SiO}_{2}$ enriched, while $\mathrm{CaO}, \mathrm{CO}_{2}, \mathrm{SO}_{3}$, L.O.I, $\mathrm{P}_{2} \mathrm{O}_{5}$, were depleted and $\mathrm{Al}_{2} \mathrm{O}_{3}$ and $\mathrm{Fe}_{2} \mathrm{O}_{3}$ were migrated and eventually concentrated in the outer zones to form Alunite and Jarosite respectively.

The same behavior applied to the trace elements, many of them were redistributed and concentrated after alteration like; $\mathrm{Ni}, \mathrm{Co}, \mathrm{Zn}, \mathrm{Ce}, \mathrm{Y}$, and $\mathrm{Li}$. Other trace elements are depleted like; $\mathrm{Cr}, \mathrm{Ag}, \mathrm{Pb}$, and $\mathrm{Cu}$.

Keywords: Neo-tectonism, Alteration zone, slickensides, Jarosite, trace elements
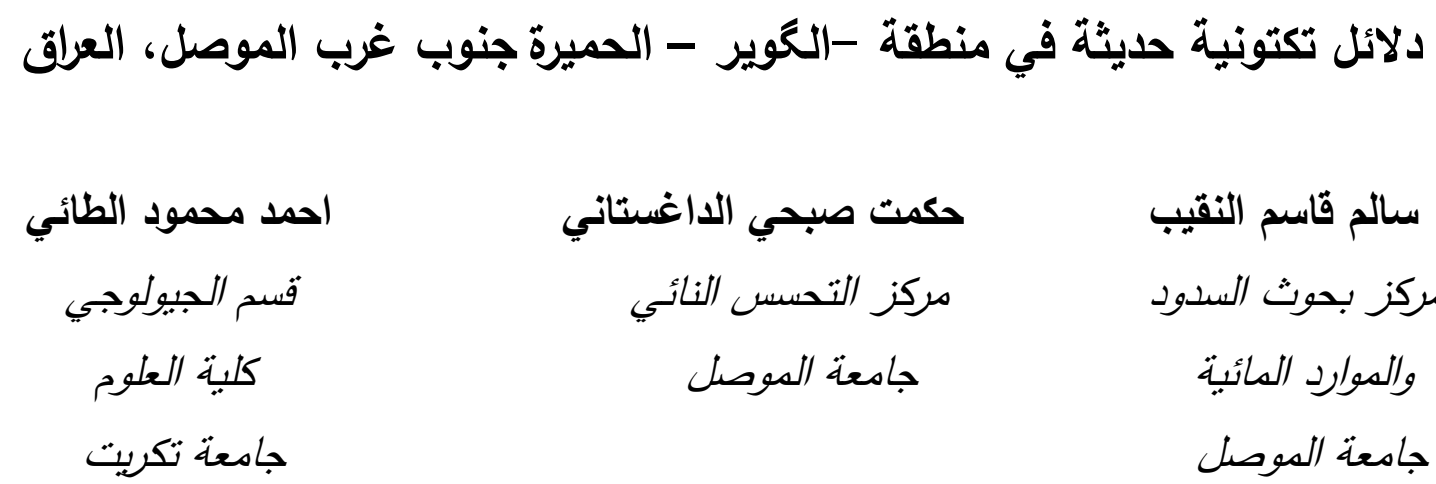

$$
\text { سالم قاسم النقيب }
$$
\end{abstract}


الملخص

تم التقاط دلائل تكتونية حديثة حول نظام فالق كركوك -نجد والذي يسير باتجاه شمال 45غرب وعلى دالى طول تراكيب الكوير، الحميرة، حاوي أصلان وزنكوبة المحدب ومن ثم مدينة الموصل وخلال حزام نهر دجلة والذي يستمر الى الحدود العراقية السورية التركية، وتتواجد صخور النينفايت خلال تلك التراكيب. وقد نم

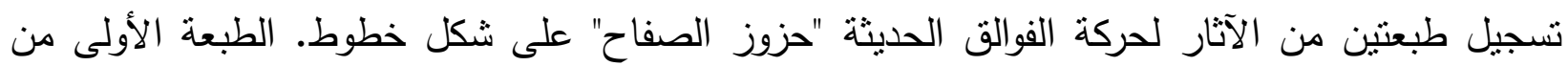
الحزوز تحصر زاوية قصية قدرها 60 درجة والطبعة الثانية من الحزوز تحصر بينها زاوية قصية قدرها 32 درجة والتي تركت آثارها على سطوح صخرة النينفايت الحديثة التكوين. وقد تم أيضاً تتفيذ دراسة جيوكيميائية

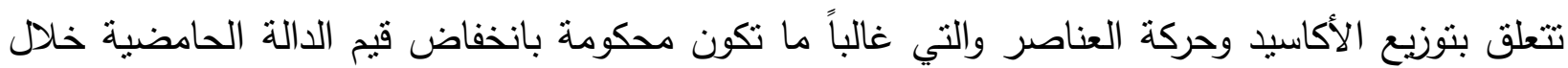

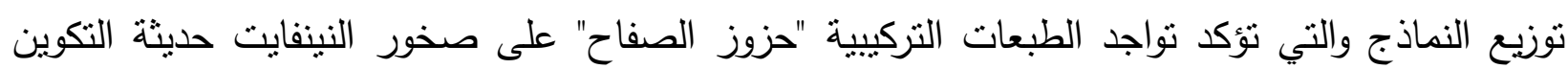
والتي تغطي النماذج المتحللة وغير المتحللة. وقد تم التقاط حدثين تركيبيين على الصخور المتحللة حديثة التكوين متمنلة بالنموذجين (14) و (16)

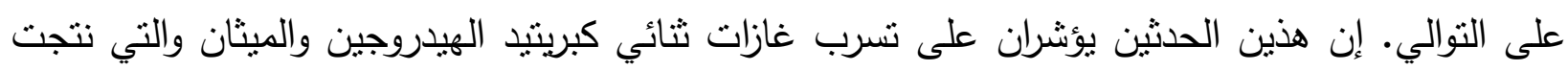

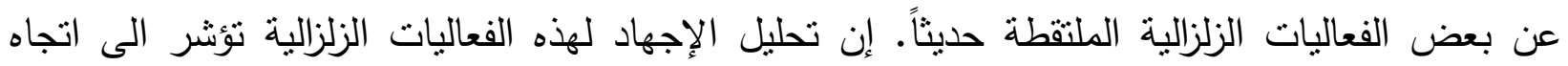

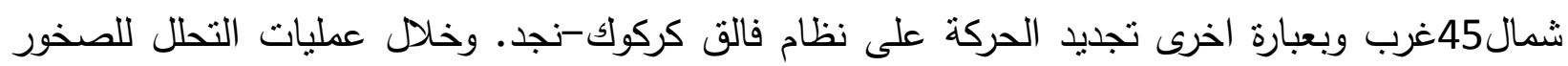

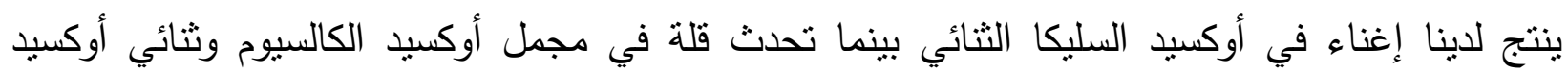
الكاربون وثلاثي أوكسيد الكبريت وخماسي أوكسيد الفسفور وكذلك الفقدان بالحرق. كما أن أوكسيد الالمنيوم

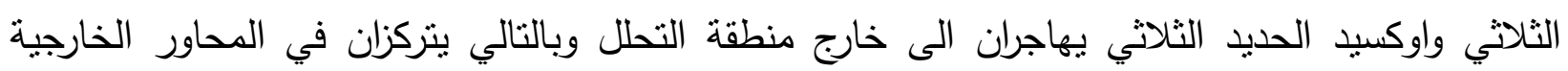

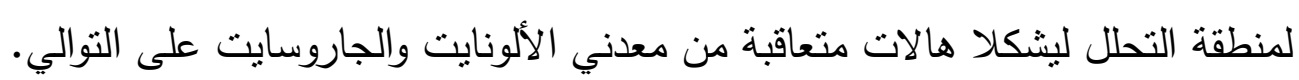

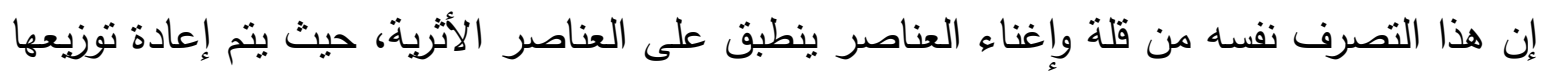

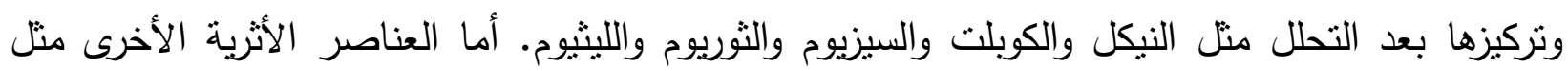

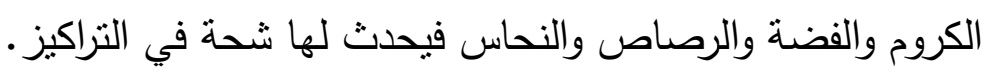
الكلمات الدالة: التكتونية الحديثة، نطاق الاحلال، حزوز الصفاح، جاروسايت، العناصر الاثارية.

\section{INTRODUCTION}

The studied area (Fig. 1) comprises the Guwair anticline on both sides of the Greater Zab River, and displays the three structural blocks: Mosul, Sinjar and Kirkuk which were mentioned by Al-Azzawi (2013). The work attempts to detect the neo-tectonic evidences acting with the present-day action of formation of Ninivite (new rock type), in combination with the accompanied $\mathrm{H}_{2} \mathrm{~S}$ upward migration pulses.

The greater Zab River is regarded as a boundary between Kirkuk and Mosul blocks according to many structural works (Buday, 1980; Numan, 1997; Al-Banaa, 
2012 and Al-Azzawi, 2013). This boundary is a zone of major fault reflecting different block basement movements twisted contemporaneously with the Alpine orogenic movements, reflected by the swing axis of Guwair anticline.

Many questions arose about the marked lithologic differences between the two sides of the Tigris River in the area from the Tigris and Greater Zab Rivers junction to the Iraqi-Syrian-Turkish borders. Some geologic formations on the eastern side like Pila Spi, Gercus, Kolosh .etc., and their rapid pinching out on the western side. On the western side of the Tigris River, the appearance of other geologic formations, like Jeribe, Euphrates, some Oligocene formations, and Jaddala are found. The remarkable facies variation of some beds of Fat'ha Formation, like the radical gypsum/anhydrite and limestones thickness on the western side and their diminishing in the eastern side. On the other hand, the appearance of sandstone, siltstone and claystone as well as the apparent disappearance of gypsum/ anhydrite and limestone beds towards east are marked. Some of these questions were answered by Al-Naqib (2006), while other questions had been answered successfully by Al-Azzawi (2013) taking the clues from tectonostratigraphic and structural (neo-tectonism) points of view during discussing the matter of fracturing the shoulders of the third bridge of Mosul city.

In the present work, new tectonic evidences were discovered in Guwair anticline. Geochemical evidence of movement and distribution of elements after rock alteration to Ninivite assured the process of $\mathrm{H}_{2} \mathrm{~S}$ gas seeping events. Later on, the tectonic activities have left their imprint on the recently formed Ninivite in the form of slickensides and fault breccias on fault plane.

Ninivite is a new sedimentary rock type discovered and described for the first time by Al-Naqib in April 1987 (Jassim and Al-Naqib, 1989; Al-Dabbagh and AlNaqib 1994; Al-Naqib and Al-Dabbagh 1993; Al-Dabbagh and Al-Naqib, 1991 and Al-Tayar, et al., 1992). It forms a belt with a maximum width of six kilometers attached to the eastern bank of the river Tigris. Many other occurrences of this rock type were recorded throughout the previous two decades in many localities along with Tigris River belt and its terraces. It is normally found within Fat'ha and Injana Formations at different stratigraphic levels exposed to the surface as well as within Tigris River terraces (Jassim et al., 1987). Ninivite occurrences were documented in the area extended from Guwair anticline to the northwest along Kirkuk-Najd fault system, passing through Humaira, Hawi Aslan, Zanquba, and Mosul and further to the northwest. 


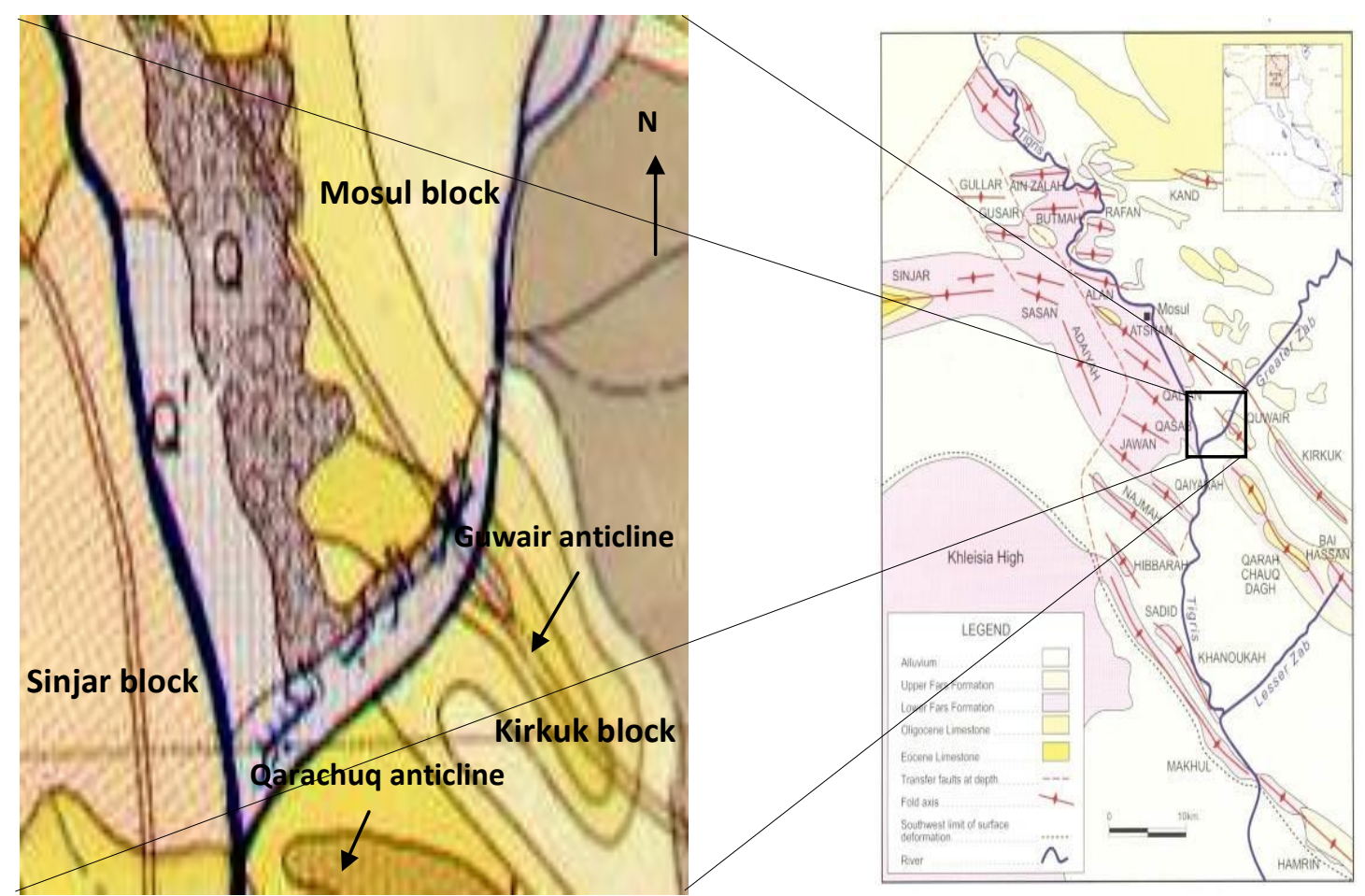

Fig 1 : Location and General Geologic Map of the Studied Area Guwair Anticline and Tigris-Greater Zab Junction, The Map to the Left after Sissakian and Fouad (2015), and the map to the right after IPC (1956)

Guwair anticline is a NW-SE trending anticline exposing the upper member of Fat'ha Formation in its core and surrounded from the northeast by Injana Formation. At the area where the Greater Zab River cuts the anticline, three main terraces levels were documented (Al-Jabbari et al., 1995). Its northwestern plunge swings more to the west-northwest.

\section{Previous works:}

Ahmad, (1980) found a deep-seated NW-SE trending basement fault along the swing axis of the northwestern plunge of Guwair anticline. (Numan and Al-Azzawi, 1993), mentioned, the basement faults marked on the earth surface by folding structures embracing major longitudinal high angle normal fault depending on the tectonic basement blocks and strike slip fault tectonism.

Al-Naqib and Al-Dabbagh (1993) defined some physical and geotechnical properties of Ninivite rock In Humaira, Hawi Aslan and Zanquba areas. Al-Jubori et al., (2001) tried to get the relative age of the river terraces of the Tigris River and they supposed the age as Pleistocene to recent. Al-Naqib, (2006) interpreted 
that, the paleo and recent genesis of Ninivite was controlled by a hydrogeological system of Tigris River, prevailing later at the time of formation of Ninivite in the core of the Guwair anticline at the late stage of the Pleistocene and the beginning of the Holocene.

\section{METHODOLOGY}

The methodology of the work is divided into:

1- Office Works: involving;

a- Google Earth Survey on Guwair anticline and defining the area of study

(Ninivite occurrences).

b- Aerial photo interpretation of Geological and geomorphologic features like folds, faults, escarpment, river terraces...etc.

2- Field Works: including

a - Detail geologic description of the concerned sampled section like color, toughness, micro structural elements (slickensides, fault breccia), attitude of bedding plane, fault plane and directions of slickensides photos.

b- Condense sampling (inch by inch) was performed in a way to cover most if not all the small and tinny features Plate (3).

c- Other observations around the area of study, like the presence of water springs and gas seepages.

3- Lab Works: including sample preparations. Samples were sent to Canada- Acme Labs (Vancouver) for major and trace elements analysis.

Twenty-one samples were analyzed in Acme Labs (Vancouver)

Ltd., 1020, cordova street East Vancouver Bc V6A 4A3 Canada for

Ninivite and related rocks persist within Fat'ha Formation in Guwair anticline.

\section{RESULT}

It can be noticed from the map of Jassim and Buday (2006), ( Fig, 2) that the present Ninivite occurrence is located precisely within the point of an intersection of Hadar-Bekhme transversal faults system with the major Kirkuk -Najd fault system and the intersection located at Guwair anticline. Photogeological interpretation was conducted prior to field work in order to ascertain the main distribution of rock types, structural and geomorphic features. The available Google image, scale, 1:6000, of the study area ( Fig. 3) was adequate for the survey. The ITC system of geomorphic symbols was used for this study.

Detailed field investigations show two main sets of slickensides accompanied with grooves and stretches along with fault breccia on the slip surface on Ninivite rock. The slickensides are naturally polished surfaces that occur when the rock along a fault rub against each other, making their surfaces smoothed, lineated and grooved (Doblas,1998), indicating the present stages of tectonism (Neotectonisims), (Plate 1).

Guwair anticline in the studied locality runs N46W, displays the direction of Najd fault system, approved by Ahmad (1980) as basement fault deduced by means of gravity method. The first slip surface has $314 / 29^{\circ}$ fault plane attitude 
embracing two sets of slickensides defining N26W directions representing the older set, cuts by younger set, S74W, confining a shear acute angle of $60^{\circ}$, (Plate1).

The second slip surface has $306 / 29^{\circ}$ fault plane attitude, embracing two sets of slickensides, having the same dip direction of the former sets, sharing older set of the first slip surface N26W with N58W younger set, confining a shear acute angle of about $32^{\circ}$, (Plate 2).

Condense sampling for the studied profile ( Plate 3) was carried out in an attempt to investigate precisely the geochemical constituents of Ninivite and its associated minerals behaviors.

The geologic map ( Fig. 1, map to the left) show Guwair anticline crossing the Greater Zab River. It is located mostly on the northern part of Kirkuk block and its northwestern plunge situated on the southern part of Mosul block. The northwestern plunge seems to have wider outcrops reflecting the dislocation occurred along the Greater Zab River.

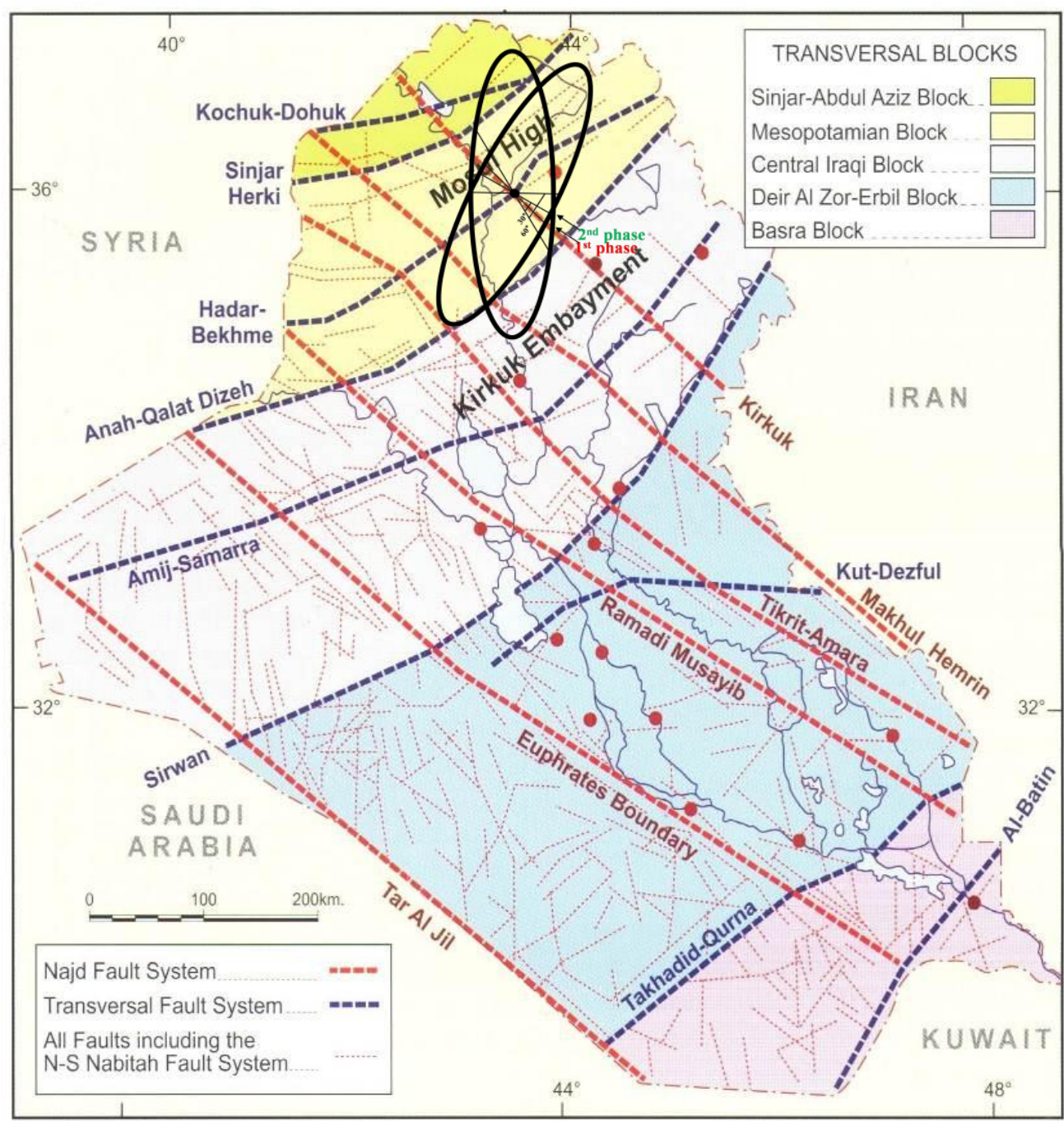

Fig. 2: Map of Iraq Showing TheTectonic Zone According to Jassim and Buday in Jassim and Goff (2006). Define the $1^{\text {st }}$ and $2^{\text {nd }}$ Phases of the Last Earthquake, 2012 at Guwair Area. 


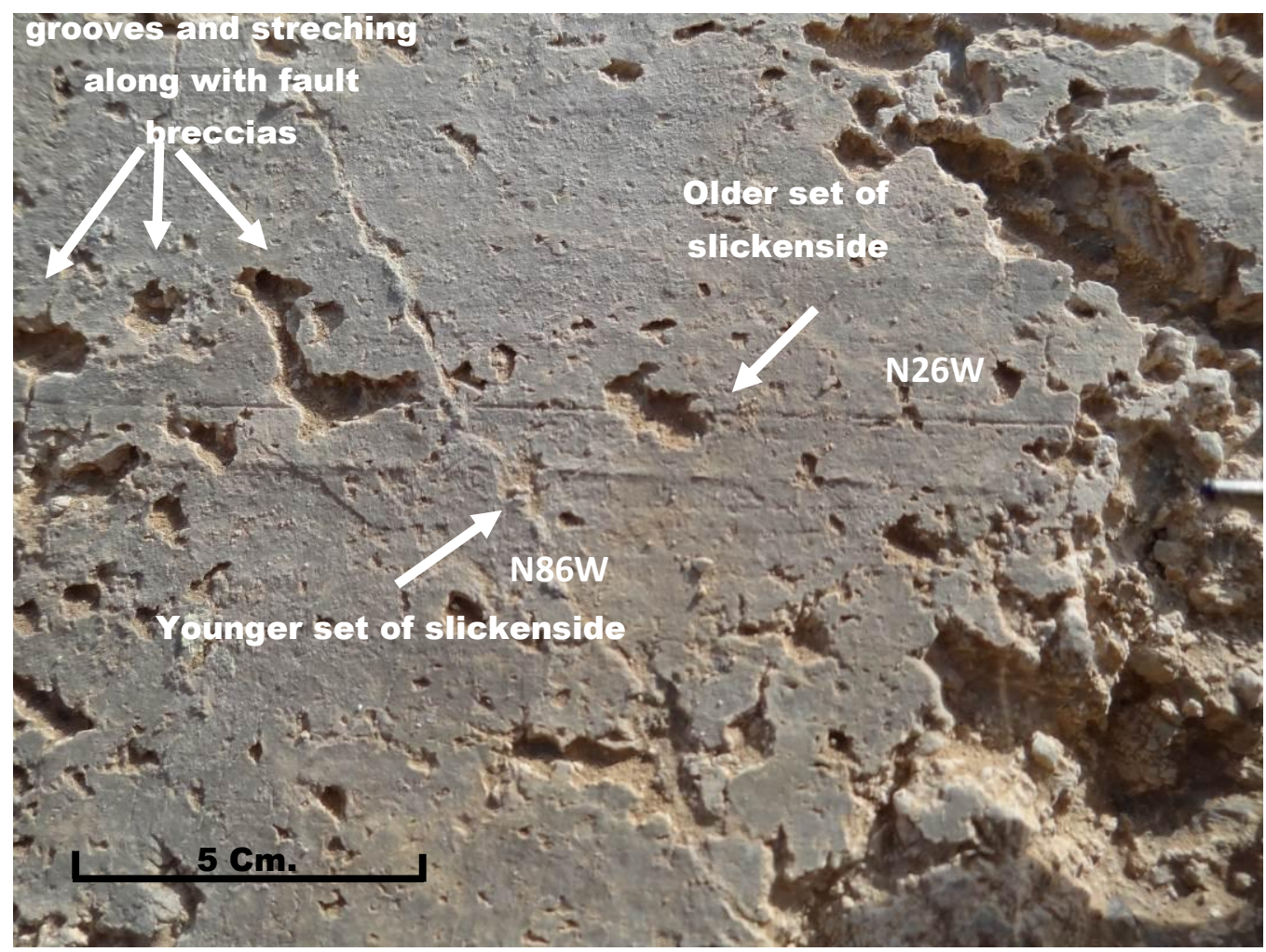

Plate 1: Ninivite Rock Showing Two Sets of Slickensides Forming $60^{\circ}$ Acute Angle with Grooves and Stretching Along with Fault Breccia.

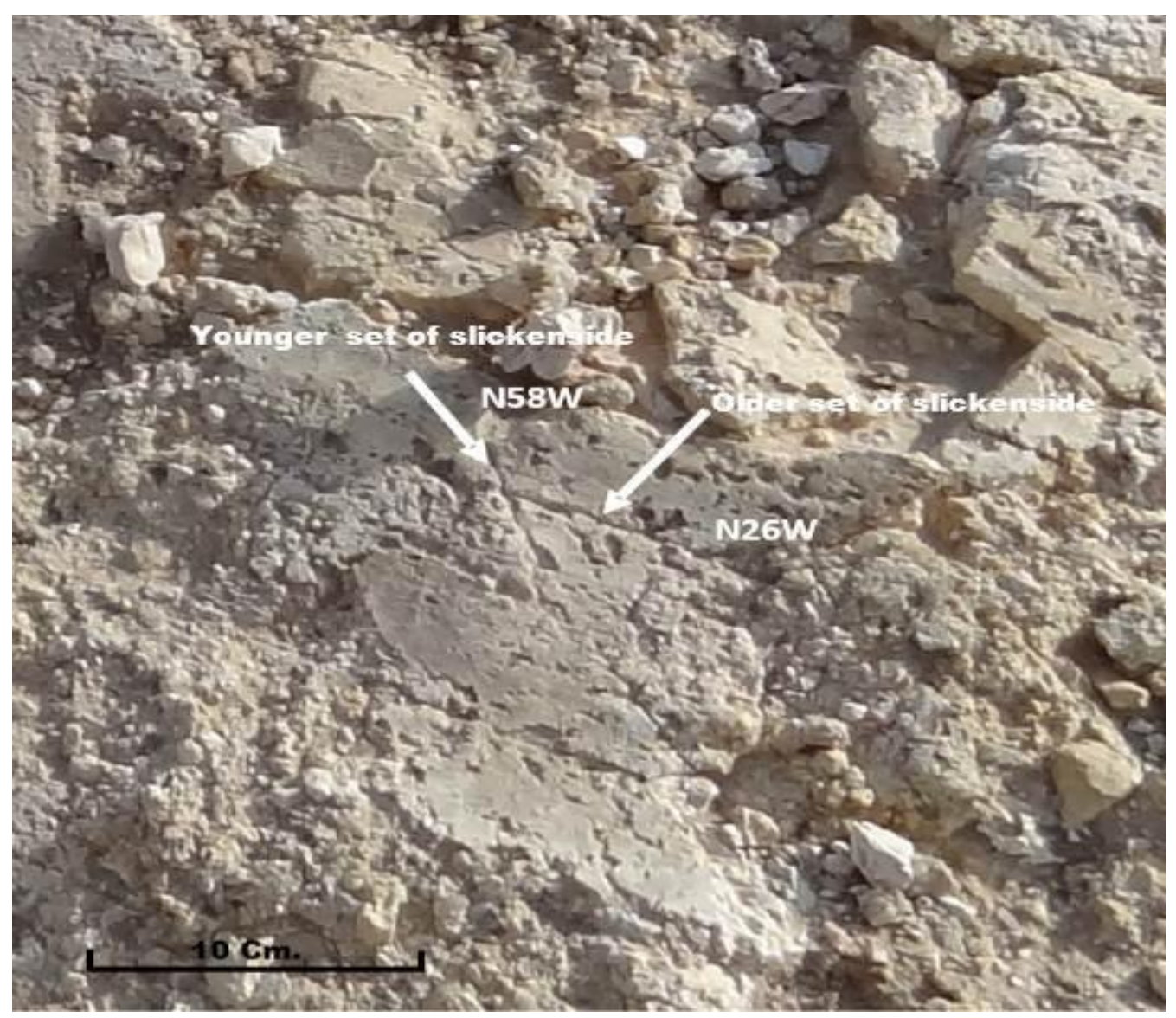

Plate 2: Ninivite Rock Showing Two Sets of Slickensides Forming $32^{\circ}$ Acute Angle and Fault Breccia. 


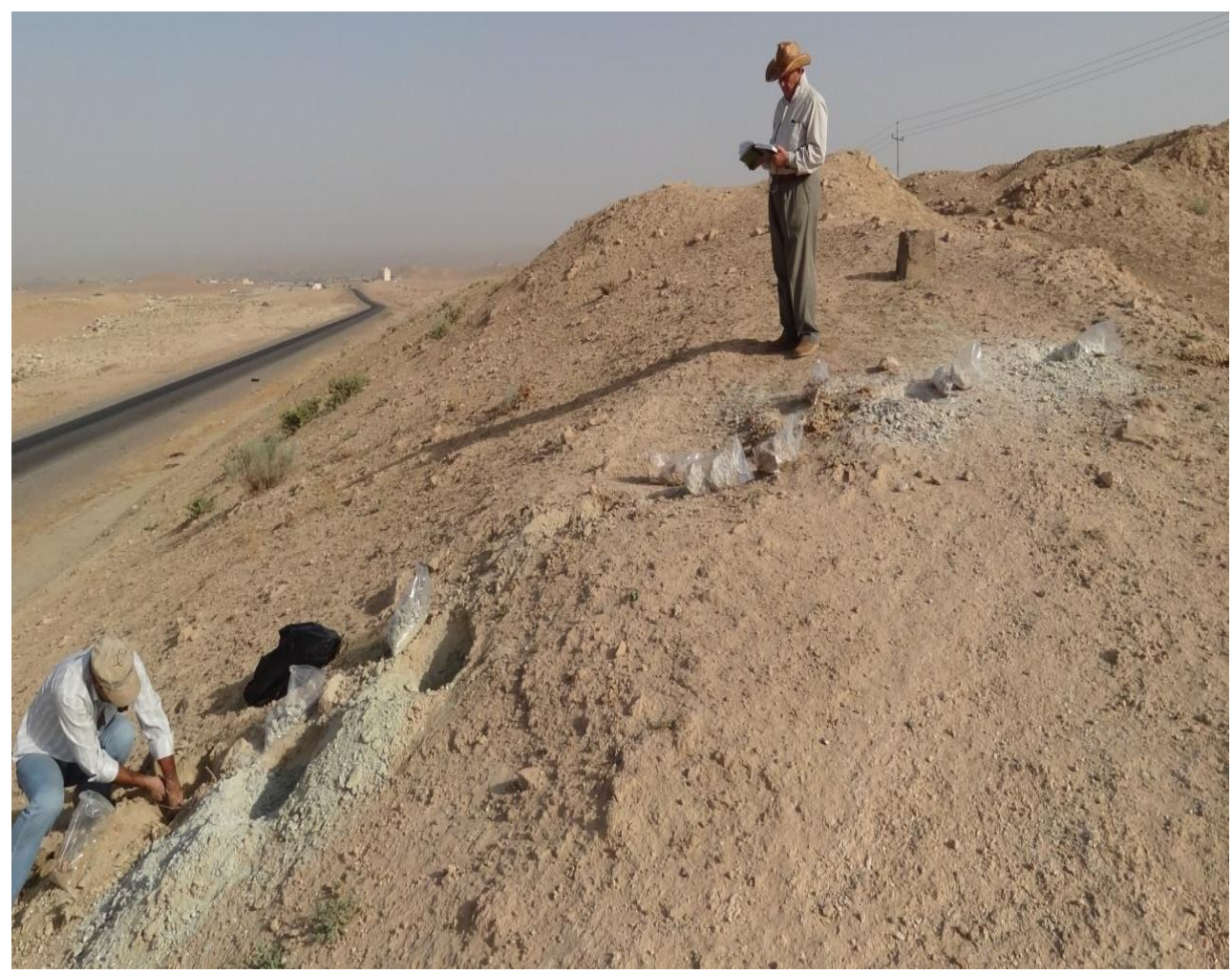

Plate 3: Condense Sampling for the Studied Ninivite

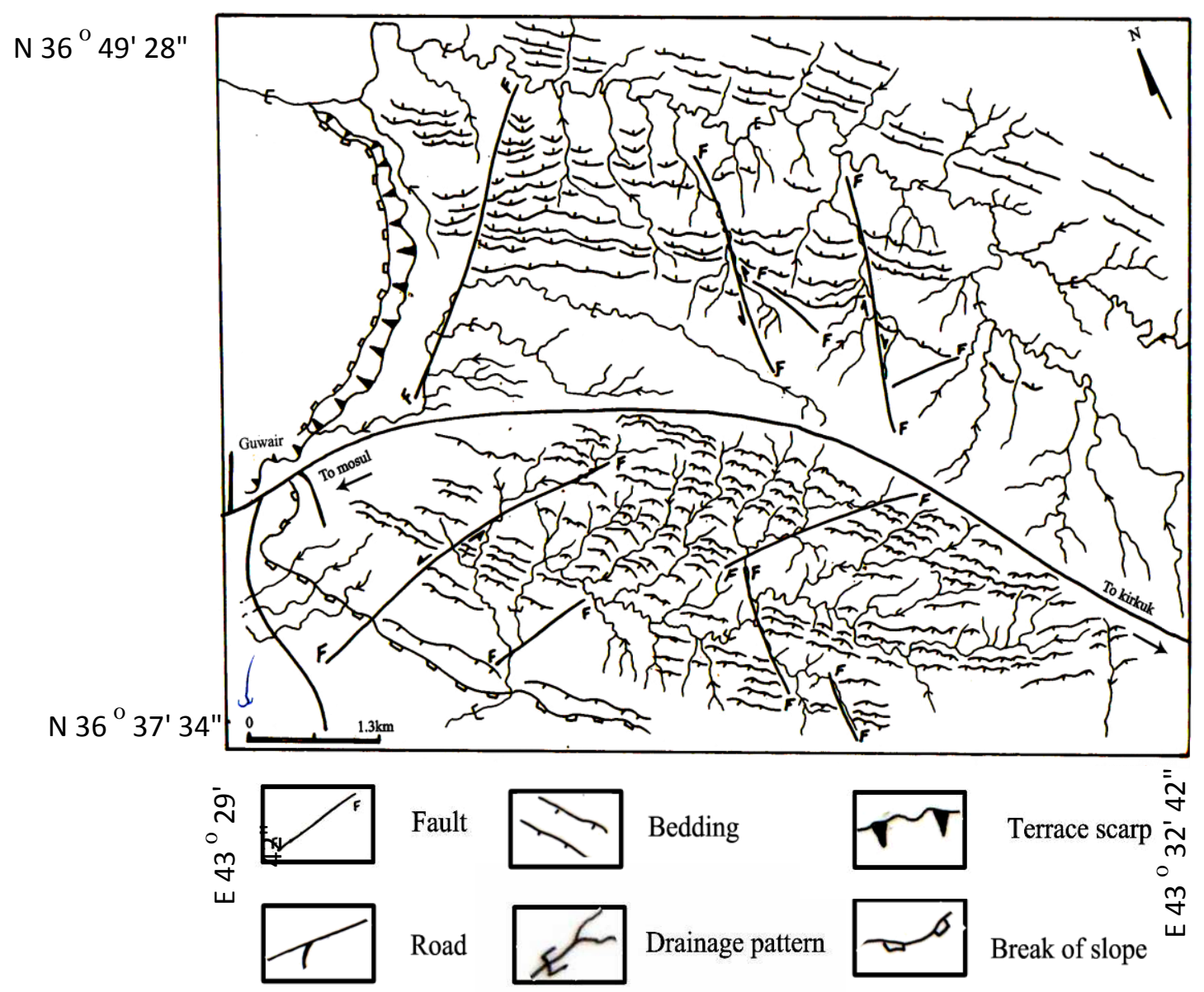

Fig. 3: Photogeological Map of Guwair Anticline. 


\section{DISCUSSION}

From the comparison of the shape of the two parts of Guwair anticline which is located within two major blocks ; Mosul and Kirkuk blocks (Fig .1) it can be deducing the following;

a. The northwestern plunge outcrop seems to be wider (within Mosul block) than the core and southeastern plunge of the anticline (within Kirkuk block). This means that the southern portion of Mosul block was tilted and uplifted, and this conclusion was also proved by drilling eight boreholes conducted by the working team on Mishraq mine $\left(\mathrm{M}_{1}\right)$ and Mishraq evaluated mine $\left(\mathrm{M}_{2}\right)$ during the eightieth of the past century. $\left(\mathrm{M}_{2}\right)$ is located in the southern edge or corner of the Mosul block.

b. The abrupt swing of the northwestern plunge with marked axial displacement about $(85 \mathrm{~m})$ could strongly argue for the major distortion and displacement caused by the major sinistral strike-slip fault runs along with the Greater Zab River. Other secondary sets of faults found within the core and limbs of Guwair anticline. These sets documented by means of small-scale slickensides occurred on fault planes within Ninivite. It refers to the present day tectonics, Plates (1) and (2).

A revised geologic mapping and detailed interpretation of Google image of Guwair anticline supplemented by fieldwork leads to the present reinterpretation. The fold limbs of Guwair anticline are cut by intermittent small-scale strike-slip faults, ( Fig. 3). The fault systems are dominated by two sets show a systematic orientation relative to the trend of fold axis. The first set strikes oblique to the trend of the Guwair anticline (NE-SW set), and the second set strikes at right angle to the first set (NW-SE set). These faults have brought a remarkable off set of the prominent escarpment of Fat'ha Formation, and offset some drainage patterns. The length of these faults varies from 0.5 to $3 \mathrm{~km}$.

As might be expected with most anticlinal folds developed in this study area, the overall drainage pattern is parallel to sub-parallel. Bedrocks and faults exert a considerable influence on drainage courses, particularly in both limbs of Guwair anticline. The lithological differences and fault movements exemplified by the local drainage diversion, into rectangular pattern (Fig . 3). The regional view afforded by remote sensing images provides valuable clues to these unknown fault systems and related features of Guwair anticline. Al-Azzawi (2013) assured the work of Ameen (1992), regarding these recent tectonic activities as a compression phase (dextral strike-slip fault), related to the neotectonics activities of the Mosul fault, and based on the orientations and opening of these fractures.

An earthquake of magnitude 2.9, date: 21.05.2012, time 00:25:19.8 UTC location $36.7 \mathrm{~N} ; 42.76 \mathrm{E}$ and $18 \mathrm{Km}$ depth, which was located on the course of the Tigris River as (Al-Azzawi, 2013) stated. Kadir (2008) discussed in a simple manner, the calculations made through measurements of stationary GPS at various 
locations, and concluded that Arabian plate moves at rate $29.99 \mathrm{~mm} / \mathrm{y}$ towards N17E, and this value was determine from IZQW of the Iraqi CORS Table (1).

Table 1: The Calculated Values of the Stationary GPS IZQW after (Kadir, 2008, in Al- Azzawi, 2013).

\begin{tabular}{|l|l|l|c|l|c|c|}
\hline $\begin{array}{l}\text { Stationary } \\
\text { GPS }\end{array}$ & Latitude & Longitude & $\begin{array}{c}\text { VX north } \\
\text { mm/year }\end{array}$ & $\begin{array}{c}\text { VY east } \\
\text { mm/year }\end{array}$ & $\begin{array}{c}\text { Velocity } \\
\text { mm/year }\end{array}$ & Azimuth \\
\hline IZQW & 35.7608 & 43.1161 & 28.62 & 8.98 & 29.99 & 017 \\
\hline
\end{tabular}

The slickensides sets are playing around the major Kirkuk-Najd Fault System with different acute angles; $60^{\circ}$ and $32^{\circ}$ reflecting two directions of movements. The faults trend directed from the SE towards NW, along Tigris River direction, controlled by NE-SW stress direction,( Fig . 2). The occurrence of slickensides with the different directions and faulting within the latest stage of Ninivite rocks in Guwair anticline may indicate with no doubt the neo (present day) tectonism is continuous. This is because; the Ninivite rock is being formed in the very recent time where, in Guwair and Humaira anticlines are continuously forming. However, any new occurrence of slickenside on Ninivite rock slip surface may indicate a new tectonic activity. Which is eventually means new $\mathrm{H}_{2} \mathrm{~S}$ gas seepages or rejuvenation of the old gases seepage may took place. At the end, this will mark a new phase of formation of Ninvite and will approved by the following geochemical investigation.

\section{GEOCHEMISTRY}

Oil, Gas and hydrocarbons accumulate under different depths and under high pressure. This lead to its movement as a reflex of the pressure, which subjected towards least pressure areas. The movement could be horizontal, inclined or vertical (API, 1996). The non-cemented fault planes are weak paths that could be suit or conduit for oil, gas and liquid migration (Awadh et al., 2010).

The presence of lesser amounts of $\mathrm{H}_{2} \mathrm{~S}$ (few ppm) displays source of oil. $\mathrm{H}_{2} \mathrm{~S}$ is a toxic and colorless gas have a density $1.39 \mathrm{~g} / \mathrm{l}$ at $25^{\circ} \mathrm{C}$ and 1 bar atmospheric pressure. Its boiling point is $60^{\circ} \mathrm{C}$. It has foul odor even if it is (1-ppm) concentration and this property gives rise to dissolution in the hydrocarbon. The origin and occurrence of $\mathrm{H}_{2} \mathrm{~S}$ gas in oil and gas accumulations relates to chemical $\&$ biological pathways. Machel, (2001) added, there are wide range of researchers believed with the biological sulphate reduction (BSR) and the thermal sulphate reduction (TSR) impact. Table (2) explains the $\mathrm{H}_{2} \mathrm{~S}$ resources. High porosity clays intend to be less porous in the presence of high percentage of $\mathrm{H}_{2} \mathrm{~S}$ gas accumulation. For the same reason, the carbonate rocks contain anhydrite are regarded as $\mathrm{H}_{2} \mathrm{~S}$ reservoir (Agard et al., 2001). 


\section{Oxides and elements movements and distribution:}

To obtain the movements and distribution of major elements as oxides percentages $(\%)$ and trace elements and some selected rare earth elements in part per million $(\mathrm{ppm})$ they are drafted into sample number. Sample numbered displays the real positions of the samples in the field relative to the alteration center cone of Ninivite and their associated minerals.

Fig (4) shows samples distributions percentages of oxides and $\mathrm{pH}$. Two $\mathrm{pH}$ depressions are noticed at samples No.14 and 16. Each $\mathrm{pH}$ depression usually occurred during certain $\mathrm{H}_{2} \mathrm{~S}$ gas pulses of gas and oil reservoirs as a result of earthquake shocks. The $\mathrm{pH}$ depression leads to dissolution of limestone and the carbonate constituents of the marl beds and other rock types. Therefore, their percentages diminished on the expanse of the radical increase of silica and other elements resistant to acidification. At samples 14 and $16, \mathrm{SiO}_{2}$ reaches about $80 \%$ whereas, $\mathrm{CaO}, \mathrm{CO}_{2}, \mathrm{SO}_{3}$, L.O.I, and $\mathrm{P}_{2} \mathrm{O}_{5}$ depleted, in addition to the marked depletion of $\mathrm{Fe}_{2} \mathrm{O}_{3}$ and $\mathrm{Al}_{2} \mathrm{O}_{3}$. It is thought that the $\mathrm{pH}$ depression at sample 14 may represents the first pulse of neo-tectonism, which is documented through the slickensides along the fault plane forming acute angle of about 60 degrees. The second pulse, recorded at sample 16, and documented through slickensides, forming acute angle of 32 degrees.

The same explanations can apply for the trace elements in Fig (5) which also documented at samples 14 and 16. Where some trace elements depleted and other concentrated.

Table 2. Main Sources of $\mathrm{H}_{2} \mathrm{~S}$ in Petroleum Accumulations.

\begin{tabular}{|l|l|l|}
\hline Origin of $\mathrm{H}_{2} \mathrm{~S}$ & $\mathbf{H}_{2} \mathrm{~S}$ generation mechanism & Main characteristics \\
\hline $\begin{array}{l}\text { Biological } \\
\text { sulphate } \\
\text { reduction } \\
\text { (BSR) }\end{array}$ & $\begin{array}{l}\text { Petroleum }+\mathrm{CaSO}_{4(\mathrm{~s})} \rightarrow \mathrm{CaCO}_{3(\mathrm{~s})}+\mathrm{H}_{2} \mathrm{~S}+\mathrm{H}_{2} \mathrm{O}+\text { contaminated } \\
\text { petroleum and bitumen }\end{array}$ & $\begin{array}{l}\text { Maximum T: c. } 80^{\circ} \mathrm{C}, \text { inhibited } \\
\text { by high levels of salinity } \\
\text { Rarely produces concentrations } \\
\text { of } \mathrm{H}_{2} \mathrm{~S} \text { in petroleum above a few } \\
\text { mole percent }\end{array}$ \\
\hline $\begin{array}{l}\text { Degradation of } \\
\text { organic } \\
\text { sulphur } \\
\text { compounds }\end{array}$ & Hydrolysis of organic sulphur compounds & $\begin{array}{l}\text { Generation of } \mathrm{H}_{2} \mathrm{~S} \text { limited } \\
\text { by the sulphur content } \\
\text { of petroleum of less than a few } \\
\text { mole percent }\end{array}$ \\
\hline $\begin{array}{l}\text { Reaction with } \\
\text { elemental } \\
\text { Sulphur }\end{array}$ & $4 \mathrm{~S}+\mathrm{CH}_{4(\mathrm{aq})}+2 \mathrm{H}_{2} \mathrm{O} \rightarrow \mathrm{CO}_{2(\mathrm{~g})}+4 \mathrm{H}_{2} \mathrm{~S}_{(\mathrm{g})}$ & $\begin{array}{l}\text { Elemental sulphur is present } \\
\text { almost exclusively as traces } \\
\text { in petroleum reservoirs }\end{array}$ \\
\hline $\begin{array}{l}\text { Volcanic } \\
\text { seepage }\end{array}$ & $\begin{array}{l}\text { The } \mathrm{H}_{2} \mathrm{~S}, \text { generated in the deep subsurface, migrates into } \\
\text { the } \\
\text { reservoir along deep fractures or faults. }\end{array}$ & $\begin{array}{l}\text { Restricted to areas } \\
\text { of volcanic activity; rarely } \\
\text { associated with hydrocarbon } \\
\text { Accumulations }\end{array}$ \\
\hline $\begin{array}{l}\text { Thermal } \\
\text { sulphate } \\
\text { reduction } \\
\text { (TSR) }\end{array}$ & $\begin{array}{l}\text { Petroleum }+\mathrm{CaSO}_{4(\mathrm{~s})} \rightarrow \mathrm{CaCO}_{3(\mathrm{~s})}+\mathrm{H}_{2} \mathrm{~S}+\mathrm{H}_{2} \mathrm{O}+\text { contaminated } \\
\text { petroleum and bitumen }\end{array}$ & $\begin{array}{l}\text { Minimum } \mathrm{T}: 120-140^{\circ} \mathrm{C} \\
\text { Requires the presence of } \\
\text { anhydrites } \\
\text { May generate percentages } \\
\text { of } \mathrm{H}_{2} \mathrm{~S} \text { up to } 95 \%\end{array}$ \\
\hline
\end{tabular}


Salim Q. Al-Naqib et al,.
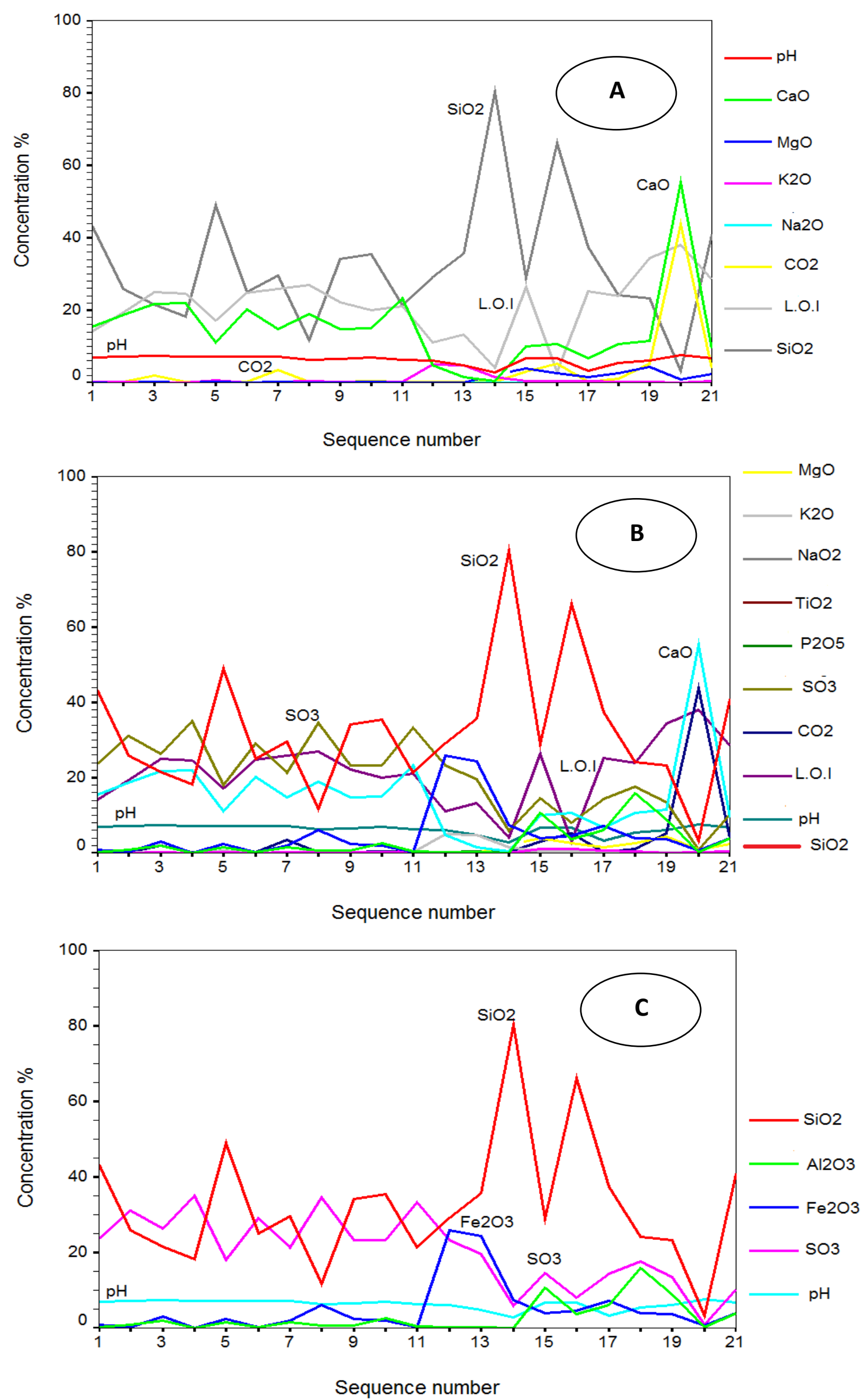

Fig. 4 :Showing The Relation of Altered and Unaltered Components (Oxides) with the Effect of pH Depressions on Sample. 
Neotectonic Evidences in Guwair - Humaira Area........
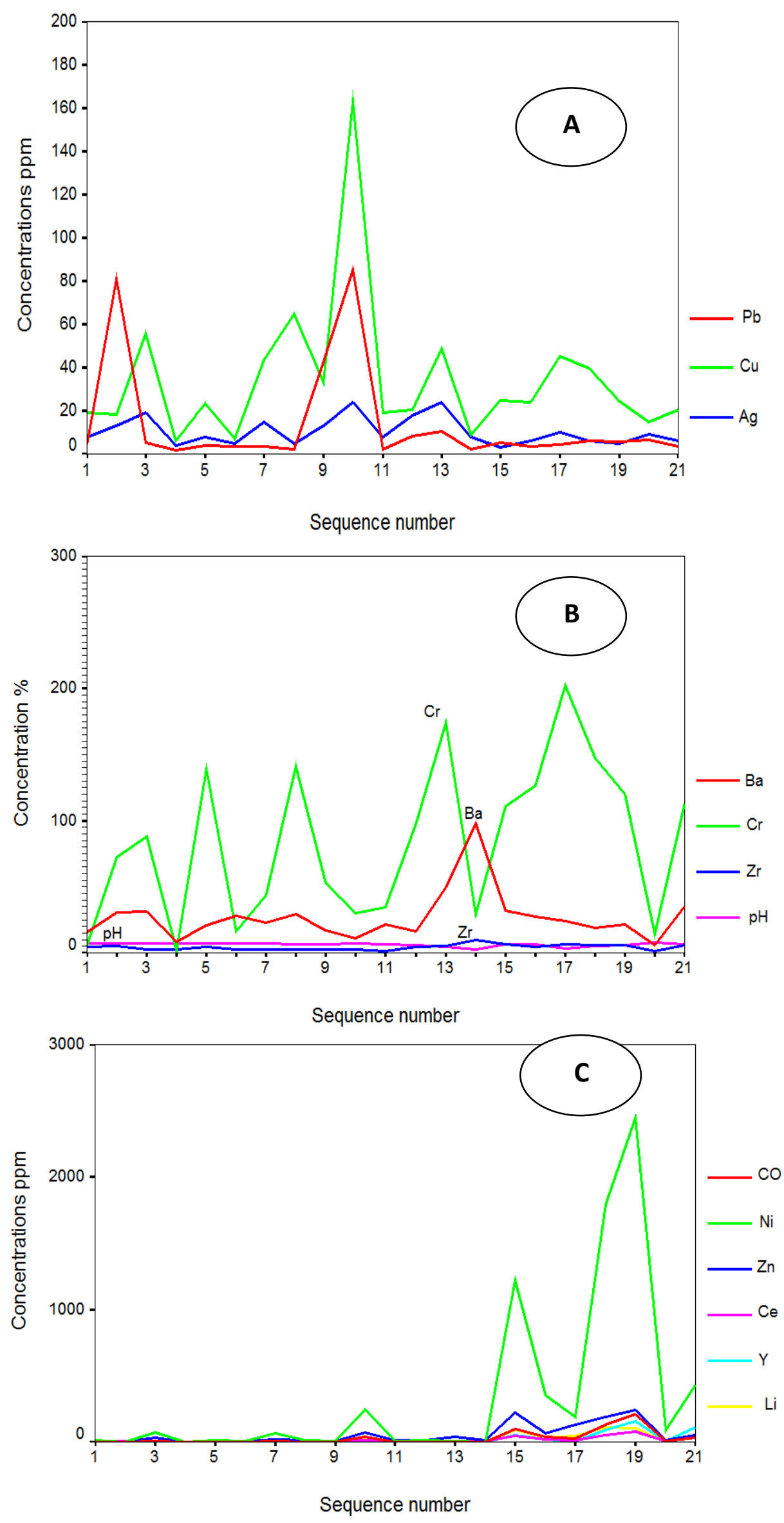

Fig. 5: Showing Trace Element Distribution within Altered and Unaltered Component of the Rock and the Effect of $\mathrm{pH}$ Depression on the Distribution of Samples. 


\section{The process of formation of Ninivite:}

Aswad et al., (1995) discussed in more detailed the process of formation of Ninivite and its associated minerals. Al-Naqib (2006) discovered more localities of Ninivite occurrences along Kirkuk-Najd fault system, which passes along with the Tigris River belt i.e. from Guwair area to the Iraqi-Syrian-Turkish borders. The migration of the seeped $\mathrm{H}_{2} \mathrm{~S}$ through faults and fracture of Fat'haFormation from oil and gas reservoirs and its oxidation, led to the formation of $\mathrm{H}_{2} \mathrm{SO}_{4}$ in the capillary zone above water table near the earth surface. Free energy (Heat) is released as a result of $\mathrm{H}_{2} \mathrm{~S}$ oxidation whereas, the reduction needs heat and result from $\mathrm{pH}$ depression. The oxidation occurred when the $\mathrm{H}_{2} \mathrm{~S}$ leaves the reduction area within the oil and gas reservoir and release upward due to reservoir pressure. This process resulted in $\mathrm{H}_{2} \mathrm{~S}$ reaction against the surrounding carbonate rocks and with calcareous claystone to form anhydrite and native Sulphur where the anhydrite become stable. These reactions which occur above oil reservoir have $\mathrm{CH}_{4}$ (Methane) effects Table (1).

The declination of $\mathrm{pH}(2.0-2.7)$ led to instability of many mineral crystal systems, resulted in the release of its most trace and even rare earth elements. These elements redistributed again according to their physio-chemical properties vis. $\mathrm{pH}$, oxidation-reduction potential in addition to the effect of anaerobic Sulphur and iron bacteria. All these effects of combination resulted in different alteration zones in the exposed rocks or top soil. These like secondary gypsum, floated selenite crystal within fractures and veins and enriched amorphous manganese zone and iron oxides and hydroxides reflecting different colors.

The above mentioned reactions and alterations happened in Fat'ha Formation in Guwair and Humaira anticlines resulted in the formation of new minerals like, Jarosite, Alunite, Goethite, adsorbed Manganse on clay mineral surfaces as well as the Formation of Ninivite rock. The later bearing high porosity, high permeability and enriched with low-density silica (Jassim and Al-Naqib, 1989 Al-Dabbagh and Al-Naqib, 1994, Al-Tayyar et al., 1992, Aswad et al., 1995 and Al-Naqib, 2006).

The anhydrite reacts with $\mathrm{CH}_{4}$ to produce $\mathrm{H}_{2} \mathrm{~S}$.

$$
\begin{gathered}
\mathrm{CaSO}_{4}+\mathrm{CH}_{4}=\mathrm{H}_{2} \mathrm{~S}+\mathrm{CaCO}_{3}+\mathrm{H}_{2} \mathrm{O} \\
2 \mathrm{H}^{+}+\mathrm{SO}_{4}{ }^{2-}+\mathrm{CH}_{4}=\mathrm{H}_{2} \mathrm{~S}+\mathrm{CO}_{2}+2 \mathrm{H}_{2} \mathrm{O}
\end{gathered}
$$

And when $\mathrm{H}_{2} \mathrm{~S}$ react with $\mathrm{O}_{2}$ the Sulphur $\mathrm{S}^{-2}$ oxidized to $\mathrm{S}^{\mathrm{o}}$ to form native Sulphur

$$
\begin{gathered}
2 \mathrm{H}_{2} \mathrm{~S}_{(\mathrm{aq})}+\mathrm{O}_{2(\mathrm{aq})}=2 \mathrm{~S}_{(\mathrm{s})}=2 \mathrm{H}_{2} \mathrm{O}{ }_{(\mathrm{l})} \\
2 \mathrm{H}_{2} \mathrm{O}_{(1)}+2 \mathrm{~S}_{(\mathrm{s})}+3 \mathrm{O}_{2(\mathrm{aq})}=2 \mathrm{HSO}_{4}^{-}(\mathrm{aq}) \\
+2 \mathrm{H}^{+}{ }_{(\mathrm{aq})}
\end{gathered}
$$

Then $\mathrm{H}_{2} \mathrm{SO}_{4}$ react with $\mathrm{CaCO}_{3}$ and marls in Guwair and Humaira areas to produce gypsum and release $\mathrm{CO}_{2}$

$$
2 \mathrm{H}^{+}+\mathrm{SO}_{4}{ }^{2-}+\mathrm{CaCO}_{3(\mathrm{~s})}+2 \mathrm{H}_{2} \mathrm{O}_{(1)}=\mathrm{Ca} \mathrm{SO}_{4} \cdot 2 \mathrm{H}_{2} \mathrm{O}_{(\mathrm{s})}+\mathrm{H}_{2} \mathrm{O}(1)+\mathrm{CO}_{2(\mathrm{~g})}
$$

The produced released $\mathrm{CO}_{2}$ can only dissolve less amount of limestone in comparison with the high amount of limestone dissolved by $\mathrm{H}_{2} \mathrm{SO}_{4}$. These may be related to the big difference of ionic constant $\left(10^{-1.9}\right)$ for $\mathrm{H}_{2} \mathrm{SO}_{4}$ and $\left(10^{-6.35}\right)$ in comparison with $\mathrm{H}_{2} \mathrm{CO}_{3}$. (Al-Taie, 2016). 


\section{Statistical Treatments:}

The sedimentary rocks are multi-sources give rise to variable chemical composition and are greatly variable in comparison with igneous rocks (Jamil et al., 1985). Accordingly, many statistical treatments for different variables were used in the data interpretation like correlation coefficient (Table 3) and factor analysis (Table 4) to find the elements relations and define their geochemical affinity. Using SPSS statistical program, three main factors were selected. (Table 3) representing $66.022 \%$ of variance. The important (Fig. 1) interprets $33.442 \%$ out of variance sum, forming two poles negative and positive. (Fig. 2) interprets $22.6 \%$ out of variance sum, and have two poles, negative and positive. (Fig. 3) interprets $9.87 \%$ out of variance sum, and have two poles negative and positive.

The effect of electron potential, ionic charge and ionic radius were very clear on elements movements and distribution through the newly formed mineral associations (Fig. 6). It is clear that (F1) positive Pole, have accumulations of aluminum and magnesium oxides and these represents clay minerals like montmorillonite and clinochlore. Some elements associate with clay minerals like manganese as oxides, or adsorbed on clay mineral surfaces, which is regarded as a trap for other elements like; Li, Ce, Y, Ni, Co. Whereas, Zn went concordant with aluminum due to their amphoritic behavior. The negative pole represents $\mathrm{Na}_{2} \mathrm{O}$, $\mathrm{CaO}, \mathrm{SO}_{3}$ and their related elements of these oxides are $\mathrm{Ag}, \mathrm{Cu}, \mathrm{Pb}$, as well as $\mathrm{Pb}$ sulphate phases like gypsum or as sulfides like $\mathrm{Ag}_{2} \mathrm{~S}$.

F (1) displays manganese zone, which precipitates as black horizons far away from iron oxides in the alteration zone. That is due to relatively higher manganese oxidation potential in comparison with iron oxidation potential. $F(2)$ positive pole displays iron oxides which precipitate in a zone far away from manganese oxides, associate with vanadium (V) due to their relatively same geochemical behaviors. $\mathrm{K}_{2} \mathrm{O}$ found within jarosite. $\mathrm{P}_{2} \mathrm{O}_{5}$ adsorbed on clay minerals. $\mathrm{TiO}_{2}$ associates with clay minerals and can replace alumina in the tetrahedral (Costa, et al., 2002). The negative pole represents Sr, L.O.I, $\mathrm{CO}_{2}$ and these related all to the carbonate phase.

Consequently, the $\mathrm{pH}$ affected largely the element movement leaving highly resisting minerals like quartz, amorphous silica, zirconium as zircon, chromium as chromite, ferrous in sulfide phase iron and barium didn't move with barium Sulphate phase and pyrite. These may be due to the share ion $\left(\mathrm{SO}_{4}\right)$ and finally the Ninivite rock formed (Fig. 4). The same manner can also apply for trace elements (Fig. 5) and assured at sample no. 14 as inflection point, some trace elements like $\mathrm{Ni}$ has radical increase after alteration. Other trace elements Co, Zn, Ce, Y, Li have the same trend of increase but with less concentrations. On the contrary to the $\mathrm{Ba}$ and $\mathrm{Zr}$ increase at the beginning of alteration they went concordant with the $\mathrm{SiO}_{2}$ at Sample No. 14, the $\mathrm{Cr}$ is depleted at that point. $\mathrm{Ag}, \mathrm{Pb}$ and $\mathrm{Cu}$ seems to be decline in concentrations after alterations. 
Table(3): Correlation coefficient of the studied Oxides and trace elements

\begin{tabular}{|c|c|c|c|c|c|c|c|c|c|c|c|c|c|c|c|c|c|c|c|c|c|c|c|c|c|c|c|c|c|}
\hline & & & & & & & & & & & & & & & & & & & & & & & & & & & & & \\
\hline & & & & & & & & & & & & & & & & & & & & & & & & & & & & & Correla \\
\hline 4 & Y & Ce & $\mathbf{u}$ & $\mathrm{Zr}$ & $v$ & $\mathrm{Cr}$ & $\mathrm{Ba}$ & Sr & $\mathrm{Cu}$ & $\mathrm{Pb}$ & $\mathrm{Zn}$ & $\mathrm{Ni}$ & Co & $\mathrm{Mn}$ & $\mathrm{Ph}$ & L.O.I & $\mathrm{CO} 2 \mathrm{~s}$ & $\mathrm{SO} 3 \mathrm{~F}$ & P2OS & $\mathrm{TO} 2$ & $\mathrm{Na} 2 \mathrm{OK}$ & $\mathrm{K}_{20}$ & $\mathrm{MgO}$ & $\mathrm{CaO}$ & $\mathrm{FeO}$ & $\mathrm{Fe} 2 \mathrm{O}$ & $\mathrm{A}_{2} \mathrm{O} 3$ & $\mathrm{SiO} 2$ & \\
\hline & & & & & & & & & & & & & & & & & & & & & & & & & & & & 1 & $\mathrm{SiO} 2$ \\
\hline & & & & & & & & & & & & & & & & & & & & & & & & & & & 1 & -0.06 & $\mathrm{~A}_{2} \mathrm{O} 3$ \\
\hline & & & & & & & & & & & & & & & & & & & & & & & & & & 1 & -0.099 & 0.145 & $\mathrm{Fe} 2 \mathrm{O}$ \\
\hline & & & & & & & & & & & & & & & & & & & & & & & & & 1 & -0.05 & 0.562 & 0.23 & $\mathrm{FeO}$ \\
\hline & & & & & & & & & & & & & & & & & & & & & & & & 1 & -0.21 & -0.5 & -0.236 & -0.64 & $\mathrm{CaO}$ \\
\hline & & & & & & & & & & & & & & & & & & & & & & & 1 & -0.21 & 0.62 & -0.14 & 0.805 & 0.126 & $\mathrm{MgO}$ \\
\hline & & & & & & & & & & & & & & & & & & & & & & 1 & -0.23 & -0.46 & -0.14 & 0.98 & -0.207 & 0.151 & K2O \\
\hline & & & & & & & & & & & & & & & & & & & & & 1 & 0.02 & -0.49 & 0.3 & -0.31 & 0.02 & -0.377 & -0.42 & $\mathrm{Na} 2 \mathrm{O}$ \\
\hline & & & & & & & & & & & & & & & & & & & & 1 & -0.12 & 0.92 & -0.08 & -0.53 & .0 .08 & 0.94 & 0.011 & 0.19 & $\mathrm{THO} 2$ \\
\hline & & & & & & & & & & & & & & & & & & & 1 & 0.9 & -0.18 & 0.95 & -0.03 & -0.53 & 0.08 & 0.94 & -0.03 & 0.259 & P2O5 \\
\hline & & & & & & & & & & & & & & & & & & 1. & -0.22 & -0.15 & 0.44 & -0.05 & -0.58 & 0.02 & -0.35 & -0.11 & -0.305 & -0.43 & $\mathrm{SO} 3$ \\
\hline & & & & & & & & & & & & & & & & & 1 & -0.55 & -0.14 & -0.19 & 0.06 & -0.16 & 0.08 & 0.79 & -0.03 & -0.16 & -0.06 & -0.36 & $\mathrm{CO} 2$ \\
\hline & & & & & & & & & & & & & & & & 1 & 0.47 & 0.03 & -0.47 & -0.42 & 0.17 & -0.45 & 0.26 & 0.59 & -0.11 & -0.41 & 0.268 & -0.79 & L.O.I \\
\hline & & & & & & & & & & & & & & & 1 & 0.34 & 0.27 & 0.32 & -0.39 & -0.45 & 0.28 & -0.35 & -0.2 & 0.58 & -0.05 & -0.42 & -0.199 & -0.48 & $\mathrm{Ph}$ \\
\hline & & & & & & & & & & & & & & 1 & -0.01 & 0.33 & 0.08 & -0.39 & -0.02 & 0 & -0.36 & -0.14 & 0.73 & -0.15 & 0.15 & -0.08 & 0.485 & 0.023 & $M n$ \\
\hline & & & & & & & & & & & & & 1 & 0.76 & -0.11 & 0.36 & 0.03 & -0.32 & -0.05 & 0.01 & -0.43 & -0.18 & 0.86 & -0.17 & 0.29 & -0.09 & 0.835 & -0.11 & $c_{0}$ \\
\hline & & & & & & & & & & & & 1 & 0.99 & 0.74 & -0.1 & 0.36 & 0.02 & -0.31 & -0.03 & 0.01 & -0.42 & -0.16 & 0.86 & -0.17 & 0.3 & -0.09 & 0.863 & -0.13 & $\mathrm{NI}$ \\
\hline & & & & & & & & & & & 1 & 0.91 & 0.92 & 0.58 & -0.25 & 0.31 & -0.03 & -0.36 & 0.04 & 0.08 & -0.47 & -0.13 & 0.9 & -0.26 & 0.52 & -0.01 & 0.911 & -0.06 & $\mathrm{Zn}$ \\
\hline & & & & & & & & & & 1 & -0.11 & -0.12 & -0.08 & -0.14 & 0.19 & -0.06 & -0.11 & 0.23 & -0.15 & -0.02 & 0.3 & -0.11 & -0.21 & 0.04 & -0.21 & -0.15 & -0.112 & -0.04 & $\mathrm{~Pb}$ \\
\hline & & & & & & & & & 1 & 0.56 & 0.12 & -0.01 & 0.05 & -0.08 & 0.03 & 0.04 & -0.15 & 0.14 & -0.05 & 0.15 & 0.08 & -0.04 & -0.21 & -0.08 & -0.05 & 0.03 & 0.078 & -0.07 & $\mathrm{Cu}$ \\
\hline & & & & & & & & 1 & -0.03 & 0.13 & -0.47 & -0.38 & -0.39 & -0.35 & 0.55 & 0.17 & 0.17 & 0.28 & -0.16 & -0.31 & 0.37 & -0.13 & -0.53 & 0.42 & -0.3 & -0.21 & -0.375 & -0.29 & $\mathrm{Sr}$ \\
\hline & & & & & & & 1 & -0.24 & -0.18 & -0.15 & -0.06 & -0.09 & -0.11 & -0.03 & -0.65 & -0.49 & -0.25 & -0.29 & 0.34 & 0.26 & -0.37 & 0.28 & 0.13 & -0.51 & -0.02 & 0.26 & -0.097 & 0.642 & $\mathrm{Ba}$ \\
\hline & & & & & & 1 & 0.11 & -0.1 & 0.11 & -0.19 & 0.48 & 0.34 & 0.33 & 0.27 & -0.41 & -0.04 & -0.22 & -0.21 & 0.5 & 0.37 & -0.08 & 0.33 & 0.39 & -0.49 & 0.43 & 0.46 & 0.489 & 0.099 & $\mathrm{Cr}$ \\
\hline & & & & & 1 & 0.76 & 0.19 & 0.35 & 0.11 & -0.19 & 0.03 & -0.03 & -0.04 & -0.02 & -0.17 & -0.14 & -0.18 & -0.07 & 0.52 & 0.31 & 0.06 & 0.43 & -0.09 & -0.35 & 0.07 & 0.47 & 0.023 & 0.124 & $v$ \\
\hline & & & & 1 & 0.18 & 0.41 & 0.68 & -0.46 & -0.22 & -0.11 & 0.43 & 0.36 & 0.34 & 0.29 & -0.67 & -0.41 & -0.29 & -0.49 & 0.41 & 0.39 & -0.5 & 0.27 & 0.67 & -0.7 & 0.26 & 0.31 & 0.411 & 0.655 & $\mathrm{Zr}$ \\
\hline & & & 1 & 0.44 & -0.01 & 0.46 & -0.08 & -0.46 & 0.05 & -0.12 & 0.97 & 0.95 & 0.93 & 0.67 & -0.19 & 0.31 & 0.03 & -0.37 & -0.01 & 0.03 & -0.45 & -0.19 & 0.92 & -0.25 & 0.53 & -0.08 & 0.959 & -0.05 & ن \\
\hline & & 1 & 0.94 & 0.4 & 0.02 & 0.38 & -0.06 & -0.35 & -0.04 & -0.15 & 0.89 & 0.96 & 0.95 & 0.84 & -0.06 & 0.37 & 0.06 & -0.42 & -0.02 & -0.03 & -0.47 & -0.2 & 0.93 & -0.18 & 0.41 & -0.13 & 0.833 & -0.04 & Ce \\
\hline & 1 & 0.95 & 0.84 & 0.36 & -0.03 & 0.31 & -0.04 & -0.39 & -0.08 & -0.16 & 0.75 & 0.89 & 0.88 & 0.94 & -0.05 & 0.42 & 0.06 & -0.37 & -0.02 & 0.01 & -0.4 & -0.16 & 0.83 & -0.16 & 0.23 & -0.09 & 0.707 & -0.08 & $Y$ \\
\hline 1 & -0.37 & -0.41 & -0.36 & -0.16 & 0.22 & 0.04 & 0 & 0.15 & 0.61 & 0.5 & -0.27 & -0.35 & -0.31 & -0.3 & -0.02 & -0.23 & -0.1 & 0.12 & 0.43 & 0.58 & 0.22 & 0.51 & -0.54 & -0.14 & -0.34 & 0.49 & -0.323 & -0 & $A g$ \\
\hline & & & & & & & & & & & & & & & & & & & & & & & & & & & & & .. \\
\hline & & & & & & & & & & & & & & & & & & & & & & & & & & & & & $\cdot$ \\
\hline iorrela & ation is & significe & cant at $t$ & the 0.0 & 1 level & (2-taled & & & & & & Rotat & ted & Corr & npon & nent & Mat & trix & & & & & & & & & & & \\
\hline iorrela & ation is & significe & cant at $t$ & the 0.05 & 5 level ( & (2-taled & & & & & & & & & & & & & & & & & & & & & & & \\
\hline & & $\mathrm{N}=21$ & & & & & & & & & & & & & & & & & & & & & & & & & & & \\
\hline
\end{tabular}


Table 4: Factor Analysis of the Studied Oxides and Trace Elements.

\begin{tabular}{|c|c|c|c|}
\hline \multicolumn{3}{|c|}{ Component } & \multirow{2}{*}{ Oxide/elemen } \\
\hline 3 & 2 & 1 & \\
\hline-.230 & .445 & .037 & $\mathrm{SIO} 2$ \\
\hline-.049 & .029 & .891 & AL2O3 \\
\hline .155 & .864 & -.128 & FE2O3 \\
\hline-.434 & .149 & .424 & FEO \\
\hline-.034 & -.798 & -.277 & $\mathrm{CAO}$ \\
\hline-.270 & -.010 & .930 & MGO \\
\hline .144 & .826 & -.216 & $\mathrm{~K} 2 \mathrm{O}$ \\
\hline .252 & -.084 & -.501 & NA2O \\
\hline .336 & .821 & .009 & $\mathrm{TIO} 2$ \\
\hline-.004 & .887 & -.052 & P2O5 \\
\hline .260 & .056 & -.447 & $\mathrm{SO} 3$ \\
\hline-.108 & -.524 & -.035 & $\mathrm{CO} 2$ \\
\hline .051 & -.623 & .316 & L.O.I \\
\hline-.083 & -.587 & -.312 & $\mathrm{PH}$ \\
\hline-.086 & -.060 & .761 & $\mathrm{MN}$ \\
\hline .060 & -.072 & .950 & $\mathrm{CO}$ \\
\hline .012 & -.066 & .947 & $\mathrm{NI}$ \\
\hline .022 & .065 & .950 & ZN \\
\hline .845 & -.100 & -.039 & PB \\
\hline .814 & .031 & -.008 & $\mathrm{CU}$ \\
\hline-.198 & -.275 & -.602 & SR \\
\hline-.341 & .605 & .051 & $\mathrm{BA}$ \\
\hline-.235 & .680 & .377 & $\mathrm{CR}$ \\
\hline-.242 & .592 & -.140 & V \\
\hline-.261 & .582 & .667 & ZR \\
\hline-.043 & .016 & .981 & $\mathrm{LI}$ \\
\hline-.115 & -.070 & .961 & CE \\
\hline-.071 & -.069 & .893 & $\mathrm{Y}$ \\
\hline .702 & .395 & -.397 & $A G$ \\
\hline
\end{tabular}

Extraction Method: Principal Component Analysis Rotation Method: Varimax with Kaiser Normalization Rotation coverage in 4 iterations. 


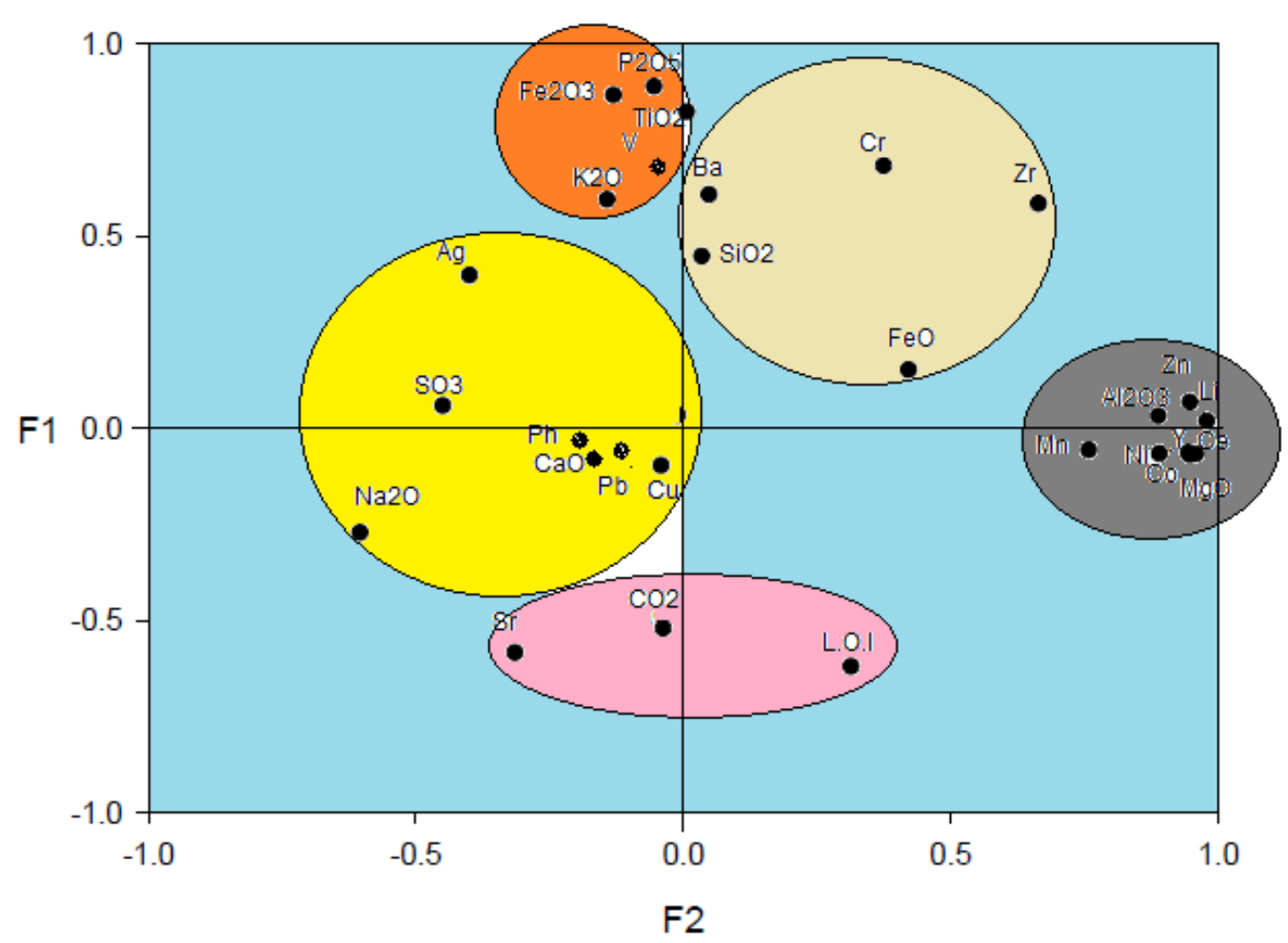

Fig. 6: Shows the Clustering of Factors (F1) and (F2).

\section{The deduced scenario of the Guwair Anticline:}

Fig (2) Show the intersection of Kirkuk-Najed fault system control Kirkuk anticline (Aqrawi et al., 2010) with Hadar-Bekhme transversal fault system directly at the core of the Guwair anticline. In addition, the sinistral- fault of NE$\mathrm{SW}$ direction also met at the intersection point. These resulted in $\mathrm{H}_{2} \mathrm{~S}$ and $\mathrm{CH}_{4}$ gas seepages at the core of the anticline and give rise to Ninivite and its associated minerals to form.

From the aforementioned studied criteria it can be concluded that; Mosul and Kirkuk blocks (Fig. 1) were twisted and interplay throughout the previous geologic history and the block boundaries were defined may be much before the deposition of the Middle-Upper Miocene. It is recently assured by the work of Al-Azzawi (2013) who built the tectonic history and the paleo stresses of Kirkuk, Mosul and Sinjar blocks.

The interplay was continued later on reflecting deep seated high angle normal fault,(at Mosul- Hammam Al-Alil Fault as it was fixed by Al-Shaikh, 1973) after the deposition of Fatha, Injanah, Muqdadiya and Bi Hassan Formations (Al-Naqib, 2006). 
With increasing the intensity of the Alpine Orogenic movement, the main folding architecture of Guwair, Humaira anticlines and other anticlines in the folded zone were developed .Some structural elements like faults may be arisen as a result of the interplay of the inherited vertical basement fault (formed pre- M. Miocene) and the horizontal movement of the Alpine Orogeny.

The interplay reshaped the boundaries of Mosul and Kirkuk blocks forming the present zone of the Tigris River and the Greater Zab River. The time spans between the shaping of Tigris River and the Greater Zab River equaled approximately to the age of the formation \&migration of the first and second stage of the Tigris River terraces Al-Jabbari et al., 1995. Later on, basement blocks were re-twisted again resulted in the relative uplifting of the southwestern boundary of Mosul block relative to northwestern boundary of Kirkuk block, to shape the present zone of Greater Zab and its present river terrace stages. The concerned retwisting was accompanied by strong effect of the orogeny leading to strike-slip displacement along the Zab zone. This was resulting in arcing and swinging the axis of the anticline towards the west-northwest with relative uplifting of the southern boundary of the Mosul block. Al-Jabbari, et al.,1995 and Al-Naqib, 2006 discussed the relationship between Tigris River terraces and Greater Zab River terraces in Guwair area with paleo ground water table and the formation of Ninivite.

Finally, although Ninivite is forming now a day, any new shear stress movement will leave its impact on it. It is regarded as neo-tectonism left its imprints on the rocks surface as shear slickensides and fault breccia. Anyhow, the major high angle normal fault intersects the recent shallow shear faulting, exhibiting a gas path to seep to the core of the studied anticlines in most recent time to form the Ninivite. These shear forces were rejuvenated again and again in the most recent time (present days) to affect Ninivite itself marking its impact as multidirectional slickensides accompanied fault breccias. Geochemically, the two $\mathrm{pH}$ drops happened to samples No. 14 and 16 assigned the $\mathrm{H}_{2} \mathrm{~S}$ seeping in most recent time.

\section{CONCLUSION}

In brief, studied structural elements; like major Mosul Kirkuk and Sinjar blocks, recognizable Kirkuk-Najed fault system intersects with Hadar-Bekhme transversal fault system at the core of the Guwair anticline and the intermittent small scale strike-slip faults which cut the succession and fold limbs of Guwair anticline. They shared to form suitable conduit for released gases from the oil and gas reservoirs. These gases when oxidize are regarded as the main sources of $\mathrm{H}_{2} \mathrm{SO}_{4}$. The later, play the main rules in the formation of Ninivite and their associated mineral zonation.

Recently propagated earthquakes recorded on the surface of the newly formed Ninivite rocks left their imprint as two sets of slickensides confining 60 
and 32 shear acute angles playing around N46W direction of Kirkuk-Najd fault system. All these evidences used to ascertain the present day tectonic activities.

Geochemically shown, the role of $\mathrm{H}_{2} \mathrm{~S}$ and other accompanied gases to decline the $\mathrm{pH}$ through certain conduits at specific time. At the end, the production of the alteration areas and the redistribution of both major and trace element and rare earth elements. The structural and the geochemical study used here to explore oil and gas production areas.

\section{REFERENCES}

Agard, P.,Jahren, J.S. and Ehrenberg, S.N., $2001 \mathrm{H}_{2} \mathrm{~S}$ Controlling Reactions in Clastic Hydrocarbon Reservoirs from the Norwegian Shelf and US Gulf Coast. In Water-Rock Interaction. 2001, Cidu R. (ed.), Swets and Zeitlinger, Lisse., pp. 129 - 132.

Ahmad, T.Y., 1980. Geophysical Investigation to the South and Southeast of Aski Kalak. Unpubl. M.Sc. Thesis, Mosul Univ., Mosul-Iraq., 87 p.

Al-Azzawi, N.K., 2013. Paleo and Neo Tectonics of the Mosul fault and its Impact on the Tectonics of the Foreland area of Iraq. Iraqi National Journal of Earth Sciences, Vol. 13, No. 1. pp. 59 - 74.

Al-Banaa, R.G., 2012. Structural Control Evaluation of Hydrocarbon Seepage in Northern Iraq Using Remote Sensing Technique. Unpublished Ph.D. Thesis, College of Science, Geology Dept. Mosul University.222 p. (In Arabic).

Al-Dabbagh, Th. H. and Al-Naqib, S. Q. 1994.Sinkhole Occurrence in Hammam Al-Alil Anticline-Northern Iraq. Jour. Water Res., Iraqi National Committee (HB), Vol. 13, No. 1 - 2, pp. 22 - 29.

Al-Dabbagh, Th. H. and Al-Naqib, 1991. Tigris River Terraces Mapping, Northern Iraq and the Geotechnical properties of the Youngest Stage near Dao AlQamar Village. Quaternary Eng. Geol., Soc., Engineering Geology, Special Publication, No. 7, pp. 603 - 609.

Al-Jabbari, H. R., Al-Naqib, S. Q. and Al-Taiee, Th.M., 1994. Preliminary Investigation of Quwair Dam, Ministry of Irrigation, Confidential report. Dams and water resources research center, Mosul University, 108p.

Al-Jubouri, A.I., Ghazal, M.M. and Al-Naqib, S.Q., 2001. Development and Heavy Mineral Analysis of the Tigris River Terraces, Northern Iraq. Dirasat, Pure and Applied Sciences, published by the deanship of academic research, University of Jordan, Amman-Jordan, Vol. 28, No. 2, pp. 245 - 259.

Al-Naqib, S.Q. and Al-Dabbagh, Th. H., 1993. Some Physical and Geotechnical

Properties of the New Rock Type Ninivite. Proc. of the 26th Annual Conference of the Geological Society-England, Bulkema, pp. 29 - 34.

Al-Naqib, S. Q., 2006. New Occurrences of Ninivite. Genesis, Field Relations and Structural and Depositional Setting in Northern Iraq. Tikrit Journal of Pure Science. Vol. 11, No. 1, pp. 239 - 244.

Al-Shaikh, Z.D., 1973. The Mosul-Hammam Al-Alil Fault and its Possible Relation to Mineral Springs of the Area. Jour. Geol. Soc. Iraq, Special Issue, pp. 69 - 78. 
Al-Taie, A. M. M., 2016. Geochemistry and Mineralogy of Fat'haFormation (Middle Miocene) that Affected by Acidic-Sulfate Water South of the City of Mosul, Northern Iraq. Unpublished Ph.D. Thesis, Mosul University, 177 p.

Al-Tayar, T.A., Mustafa, M.H. and Al-Naqib, S. Q., 1992. Investigation of Tigris River Pollution. Proc. 181' WEDC Conf. Water, Environment and Management, Nepal Engin. Assoc. Kathmandu-Nepal, 30 August-3 Sept., pp. 51- 54.

Ameen, M.S., 1992. Effect of Basement Tectonic on Hydrocarbon Generation. Petrolium Geologists Bulliten, Vol. 76, No. 3, pp. 356 - 370.

API, 1996. A Guide to the Assessment and Remediation of Underground Petroleum Releases, 3rd edition. American Petroleum Institute Publication 1628, Washington, DC.

Aqrawi, A.A., Goff, J.C., Horbury, A.D., Sadooni, F.N., 2010. The Petroleum Geology of Iraq. Scientific Press, Great Britain. Sour oil and Gas Management Encyclopedia of Hydrocarbons, Vol. III/New Developments: Energy, Transport, Sustainability.

Aswad, Kh. J., Amin, M.A. and Al-Naqib, S.Q., 1995. Marl-H 2 S Interaction Under Surfacial Oxidizing Condition, Dirasat, Pure and Applied Sciences, Published by the Deanship of Academic Research, University of Jordan .AmmanJordan, Vol. 22B, No.6, , pp. 1541 - 1561.

Awadh, S.M., Al-Ameri, T.K., Sahar, Y.J., Bayraktutan, S.M., 2010. Fluid Inclusions Used to Assess Oil Migration in Duhok, North Iraq. Positioning, Scientific Research, Vol. 2, pp. 42 - 49 [ In Geochemical Exploration Using Surveys of Spring Water, Hydrocarbon and Gas Seepage, and Geobotany for Determining the Surface Extension of Abu-Jir Fault Zone in Iraq: A New Way for Determining Geometrical Shapes of Computational Simulation Model. Journal of Geochemical Exploration, Vol. 124, 2013. pp. 218 - 229.

Buday, T., 1980. The Regional Geology of Iraq. Vol. I.: Stratigraphy and Paleogeography. GEOSURV, Baghdad, $445 \mathrm{p}$.

Costa, G.M de, Vanson, E., De Grave, Vandenberghe, R. E, Barron, V. and Datas, L., 2002. Al hematite ore pared by homogeneous precipitation of oxinates: Material Characterization and Determination of the Marine Transition, Phys. Chem. Minerals, Vol. 29, pp. 122 - 131.

Doblas, M., 1998. Slickensides Kinematic Indicators. Tectonophysics, Vol. 295, pp. 187 - 197.

IPC, 1956. Geological occurrence of oil and gas in Iraq. Symposium Sorbe Yacimientos de Petroleo y Gas. XX. Congress Geologico Internationational. pp.73 - 101.

Jamil ,A. K., Al-Biaty, H.J. and Ali, A.A., 1985. Hydrogen Sulphide Pollution of Tigris River - Iraq. Iraqi Sci., Vol. 26.

Jassim, S. Z. and Al-Naqib, S.Q. 1989. Ninivite, A New form of Porcelainite and the Associated Alunite, and Jarosite Minerals. A Suite Related to Sulphuric 
Acid Seepages, South of Mosul, Northern Iraq. Jour. Geol. Soc. Iraq. Vol. 22, No. 1., pp. 112-122.

Jassim, S. Z. and Al-Naqib, S.Q. and Nooh, Y., 1987. The Occurrence of Porcelainite in Niniva Governarate-Sylamia Area. E. G. Geol. Surv. and Mineral Invest, Baghdad, Unpubl. Report No. 1734, 36p.

Jassim, S. Z. and Goff, J.C., 2006. Geology of Iraq. Olin, Prague Ang Moravian Musiu, Berno, 341p.

Kadir, M.M., 2008. Geodynamic Study of the Northeastern Margin of the Arabian Plate. Unpublished Ph.D. thesis, University of Mosul, Iraq, 206p.

Machel, H.G., 2001. Bacterial and Thermochemical Sulfate Reduction in Diagenetic Settings - Old and New Insights, Sedimentary Geology, Vol. 140, pp. 143 - 175.

Numan, N. and Al-Azzawi, N., 1993. Structural and Geotectonic Interpretation of Vergence Directions of Anticlines in the Foreland Fold of Iraq. Abbath AlYarmouk Pure Science and Engineering Series, Vol. 2, No. 2, pp. 57 - 73.

Sissakian, V.K. and Fouad, S.F., 2015. Geological Map of Iraq, Scale 1:1000 000 4th ed., Iaqi Bulletin of Geology and Mining, Vol. 28, pp. 123 - 149. 